\title{
NOMOPHOBIA: A META-ANALYTIC REVIEW
}

\author{
Fathimath suhara KT* Maneesha.K.P* Sannet Thomas ** \\ *I MSc psychology students, Yuvakshethra Institute of management studies, Palakkad, \\ Kerala-678631 \\ **Assistant professor of Yuvakshethra Institute of Management studies, Palakkad, \\ Kerala -678631
}

Article DOI: https://doi.org/10.36713/epra7145

DOI No: 10.36713/epra7145

\begin{abstract}
Nomophobia is No mobile phone phobia. It is described as the dread of being besides a bendy device or past adaptable cell phone contact. Nomophobia is on the ascent over the globe. Here the inspector prepared to journey the contemplates directed in India simply as outside to have a good sized comprehension on the thinking of nomophobia, its estimations, system of consider, associated ideas, proposals etc. The professionals used meta-examination as the system for shifting closer the issue. Ten ponders which met the idea measures had been picked for this consider. Revelations of the reflect on consideration on offers the thinking that nomophobia is primary among all age packs, the majority of the contemplates directed in school understudies. Nomo phobic humans have physical, social and mental issues. Mental troubles consolidates stretch, disquiet, wretchedness, bitterness and so forth Causal elements of nomophobia is ordinary round the planet.
\end{abstract}

KEYWORDS: Nomophobia

\section{INTRODUCTION}

New technological gadgets and virtual communication are essential asset to the world. Computers, tablets and cell telephones (smart phones) are presenting comfort to human beings specially to young humans in each section of their lives such as; connecting to the Internet, taking photos, listening to radio and music, following the news, discovering addresses and route, making reservations, banking, shopping, playing games etc. At the same time the developing technological units and virtual communication produce each pons and cons to the world, cons encompass social problems like social isolation, economic/financial issues like large money owed incurred to buy or use clever phones. It can additionally purpose each physical and psychological pathologies like damages related to electromagnetic field radiation, auto accidents, distress linked to the concern of no longer being capable to use new technological devices. When the use of these gadgets increases the severe feeling of anxiety and misery additionally increases telephone addiction its known as nomophobia. Nomophobia is viewed a modern age phobia currently as a derivative of our interactions with cellular phones (Yildirim and Correia, 2015). Nomophobia is an acronym for no cellular cellphone phobia, it is the concern of being unable to use one's cell smartphone or being unreachable via one's mobile phone, and refers to the feelings of discomfort or anxiousness experienced by way of individuals when they are unable to use their mobile telephones or make use of the affordances these units provide. An adjective, the time period Nomo phobic is used to describe the characteristics of behaviours' related to nomophobia. Mobile Phone Phobia (nomophobia) may be viewed as one of the troubles experienced through a society. Nomophobics trip anxiousness which people face when they feel they may want to now not get sign from a cell tower, run out of battery, forget about to take the phone with them or genuinely do not receive calls, texts or electronic mail notifications for a certain duration of time, Ringxiety (a portmanteau of ring and anxiety) is also known as, Phantom vibration syndrome", phantom ringing, hypovibrochondria fauxcellarm, which capability a false sensation of ringing of 
mobile phones. The most everyday symptoms of nomophobia pronounced that headache and lethargy, thermal sensation within the auricle and behind/around the ear, impaired attention and facial dermatitis.SecurEnvoy, (2012) described Nomophobia is a time period which is used to describe "the fear of being out of cellular phone contact" and the "anxieties cell telephone customers suffer". King, Valence, Silva, Baczynski, Carvalho \& Nardi,( 2013) defined nomophobia is viewed a ailment of the modern world, and has only recently been used to describe the pain or anxiousness triggered by means of the non-availability of an MP [mobile phone], PC [personal computer] or any other virtual verbal exchange device in men and women who use them habitually .Similarly, King, Valenca, Silva, Sancassiani, Machado and Nardi (2014) considered nomophobia as a present day fear when one is unable to communicate by means of the use of a cellular smartphone or Internet. It is "a situational phobia associated to agoraphobia and consists of the fear of becoming ill and no longer receiving immediately assistance" .Yildirim (2014) asserted that it as a concern of now not being able to use a smartphone or a mobile telephone and/or the offerings it offers. It refers to the worry of now not being in a position to communicate, losing the connectedness that smartphones allow, now not being able to get admission to facts thru smartphones, and giving up the convenience that smartphones grant (Yildirim, 2014; p. 74). King et al., (2014); Yildirim $\&$ Correia, (2015) referred it as a worry and soreness from not having get right of entry to to one's mobile system is a phenomenon that has end up extra recognized. In the literature of mobile phone smartphone dependency. Han et al defined nomophobia as a smartphone separation nervousness and argued that when a user perceives the smartphone as an prolonged self, he or she is more possibly to get attached to the system which in flip lead to nomophobia through promoting proximity searching for.

\section{OBJECTIVE}

To analyse research studies on nomophobia and to have a deep understanding on the concept of nomophobia and its related concepts.

\begin{tabular}{|l|c|c|c|}
\hline SN & $\begin{array}{c}\text { Author(s) } \\
\text { and year }\end{array}$ & $\begin{array}{c}\text { Name } \\
\text { of the } \\
\text { study }\end{array}$ & Major findings \\
\hline 1 & $\begin{array}{c}\text { Caglar Yildirim } \\
\text { Evren Sumue } \\
\text { Muge Adnan and } \\
\text { Soner Yildirim (2015) }\end{array}$ & $\begin{array}{c}\text { A growing fear: } \\
\text { Prevalence } \\
\text { of nomophobia } \\
\text { among Turkish } \\
\text { college students }\end{array}$ & $\begin{array}{c}\text { The results revealed } \\
42.6 \% \text { of young adults } \\
\text { had nomophobia, and } \\
\text { Their greatest fears } \\
\text { were related to } \\
\text { communication and } \\
\text { information access. The } \\
\text { study also found that }\end{array}$ \\
\hline
\end{tabular}

\section{METHODOLOGY}

\section{Literature search}

A pc based totally statistics search was carried out on the Info Net- a laptop database, which affords abstracts and full paper of articles. Studies from January 2015 up to October 2019 have been protected in the search. Google scholar, Science Direct, PubMed, J stor, Springer, Wiley, Taylor and Francis were searched the use of "nomophobia" as key-word to search for papers posted from January 2015 to October 2019. Many studies have been recognized by using the above keywords. Study abstracts obtained had been read to eliminate research that were not worried with nomophobia. These steps produced a pool of 10 studies that met inclusion criteria.

Inclusion criteria

The study aimed at understanding the concept of nomophobia. Only full text studies were included. Qualitative studies, reviews, articles which focus mainly on nomophobia were also included. Another inclusion criterion was that study must be written in English language and finally the study must have been conducted between January 2015 and 2019.

\section{Procedure}

First of all the selected studies were arranged according to the year of publishing (from 2015 to 2019), then extracted major findings of the studies and then each study was analysed qualitatively. These selected studies were arranged according to the publishing year. Then they are consolidated and analysed using content analysis.

\section{RESULT AND DISCUSSION}

The collected studies were arranged in the order of publication and analysed using already identified factors and some factors were also emerged during the analysis process. The arrangement of selected studies and their classification were presented in table 1 . 


\begin{tabular}{|c|c|c|c|}
\hline & & & $\begin{array}{l}\text { gende rand the duration } \\
\text { of smartphone } \\
\text { ownership had an effect } \\
\text { on young adults' } \\
\text { nomophobic behaviours, } \\
\text { whereas age and the } \\
\text { duration of mobile } \\
\text { phone ownership had no } \\
\text { effect. }\end{array}$ \\
\hline 2 & $\begin{array}{c}\text { Pavithra MB, Suwarna } \\
\text { Madhukumar and } \\
\text { Mahadeva Murthy TS } \\
\text { (2015) }\end{array}$ & $\begin{array}{l}\text { A study on } \\
\text { nomophobia } \\
\text { mobile phone } \\
\text { dependence, } \\
\text { among students } \\
\text { of a medical } \\
\text { college in } \\
\text { Bangalore }\end{array}$ & $\begin{array}{l}\text { Majority (74\%) of the } \\
\text { students spent Rupees } \\
\text { 300-500 per month on } \\
\text { mobile recharge. About } \\
\text { 23\% students felt they } \\
\text { lose concentration and } \\
\text { become stressed when } \\
\text { they do not have their } \\
\text { mobile around, } \\
79(39.5 \%) \text { students } \\
\text { were Nomopobic in this } \\
\text { study and another } 27 \% \\
\text { were at risk of } \\
\text { developing Nomophobia. }\end{array}$ \\
\hline 3 & $\begin{array}{l}\text { Neelima Sharma, Pooja } \\
\text { Sharma, Neha Sharma } \\
\text { and R. RWavare(2015) }\end{array}$ & $\begin{array}{l}\text { Rising concern of } \\
\text { nomophobia } \\
\text { amongst Indian } \\
\text { medical students }\end{array}$ & $\begin{array}{l}\text { Students were having } \\
\text { possession of at least } \\
\text { one mobile phone with } \\
\text { activated internet } \\
\text { services in } 87 \% \text { of } \\
\text { students. } 34 \% \text { were } \\
\text { having two mobile } \\
\text { phones, while 4\% had } \\
\text { more than two mobiles. } \\
\text { 61\% students had to } \\
\text { recharge the internet } \\
\text { services once a month, } \\
28 \% \text { twice a month, } \\
\text { while } 11 \% \text { students had } \\
\text { to recharge it more than } \\
\text { three times a month. } \\
73 \% \text { of students were } \\
\text { nomophobics. } 21 \% \text { of } \\
\text { nomophobics } \\
\text { experienced rinxiety. } \\
83 \% \text { of students } \\
\text { experienced panic } \\
\text { attacks when their } \\
\text { mobile phone was } \\
\text { misplaced. Headache } \\
\text { and lethargy were the } \\
\text { commonest side effects } \\
\text { that were experienced } \\
\text { by } 61 \% \text { of students }\end{array}$ \\
\hline
\end{tabular}




\begin{tabular}{|c|c|c|c|}
\hline 4 & $\begin{array}{l}\text { Ibrahim Arpaci, } \\
\text { Mustafa Baloglu, } \\
\text { Hatice Irem Ozteke and } \\
\text { Sahin Kesici (2017) }\end{array}$ & $\begin{array}{l}\text { Individual } \\
\text { Differences in the } \\
\text { Relationship } \\
\text { Between } \\
\text { Attachment and } \\
\text { Nomophobia } \\
\text { Among College } \\
\text { Students: The } \\
\text { Mediating Role of } \\
\text { Mindfulness }\end{array}$ & $\begin{array}{c}\text { The structural equation } \\
\text { model shows that the } \\
\text { positive direct effects of } \\
\text { avoidant }(.13, \mathrm{P}=.03) \\
\text { and anxious attachment } \\
\text { (.48, P<.001) on } \\
\text { nomophobia were } \\
\text { significant. The negative } \\
\text { direct effects of avoidant } \\
(-.18, \mathrm{P}=.01) \text { and } \\
\text { anxious attachment } \\
\text { (-.33, P<.001) on } \\
\text { mindfulness were also } \\
\text { significant. Moreover, } \\
\text { mindfulness has a } \\
\text { significant negative } \\
\text { effect on nomophobia } \\
\text { for women only } \\
\text { (-.13, } \mathrm{P}=.03) . \text { Finally, the } \\
\text { Sobel test showed that } \\
\text { the indirect effects of } \\
\text { avoidant and anxious } \\
\text { attachment on } \\
\text { nomophobia via } \\
\text { mindfulness were } \\
\text { significantly higher than } \\
\text { men (mean } 63.59 \text { [SD } \\
15.97]) \text { in anxious } \\
\text { attachment } \\
\text { (F1 }=7.93, \mathrm{P}=.01 \text {, } \\
\text { partial } \eta 2=.02) . \text { Gender } \\
\text { differences in } \\
\text { mindfulness were not } \\
\text { significant (F4, } \\
448=3.45, \mathrm{P}=.69) . \text { On the } \\
\text { other hand, results do } \\
\text { show significant gender } \\
\text { differences in } \\
\text { nomophobia (F4, } \\
445=2.71, \mathrm{P}=.03, \text { Wilk } \\
\lambda=.98, \text { partial } \eta 2=.02) \\
\text { where women scored } \\
\text { significantly higher than } \\
\text { men. }\end{array}$ \\
\hline 5 & $\begin{array}{c}\text { Deniz Mertkan } \\
\text { Gezgin, Nazire Burcin } \\
\text { Hamutoglu, Gozde } \\
\text { Sezen-Gultekin and } \\
\text { Tuncay Ayas (2018) }\end{array}$ & $\begin{array}{c}\text { The } \\
\text { Relationship } \\
\text { between } \\
\text { Nomophobia } \\
\text { and Loneliness } \\
\text { among Turkish } \\
\text { Adolescents }\end{array}$ & $\begin{array}{c}\text { Levels of nomophobic } \\
\text { behaviors of } \\
\text { adolescents were at a } \\
\text { moderate level. While } \\
\text { there was not a } \\
\text { statistically significant } \\
\text { correlation in terms of } \\
\text { the duration of } \\
\text { smartphone } \\
\text { ownership and } \\
\end{array}$ \\
\hline
\end{tabular}




\begin{tabular}{|c|c|c|c|}
\hline & & & $\begin{array}{c}\text { monthly mobile } \\
\text { internet GSM quota, a } \\
\text { significant difference } \\
\text { was found in terms of } \\
\text { the duration of mobile } \\
\text { internet ownership, } \\
\text { the duration of daily } \\
\text { mobile internet use, } \\
\text { and daily smartphone } \\
\text { checking time. Finally, } \\
\text { there was a } \\
\text { statistically significant } \\
\text { relationship between } \\
\text { nomophobia and } \\
\text { loneliness, and it can } \\
\text { be ascertained that } \\
\text { loneliness of } \\
\text { adolescents predicts } \\
\text { their nomophobia } \\
\text { levels to a certain } \\
\text { extent. }\end{array}$ \\
\hline 6 & $\begin{array}{l}\text { Burhanettin Ozdemir, } \\
\text { Ozlem Cakir and } \\
\text { Irshad Hussain (2018) }\end{array}$ & $\begin{array}{c}\text { Prevalence of } \\
\text { Nomophobia } \\
\text { among University } \\
\text { Students: A } \\
\text { Comparative } \\
\text { Study of Pakistani } \\
\text { and Turkish } \\
\text { Undergraduate } \\
\text { Students }\end{array}$ & $\begin{array}{c}\text { According to } \\
\text { multivariate effects } \\
\text { results, the main effect } \\
\text { of gender on self-esteem } \\
\text { and nomophobia was } \\
\text { statistically significant } \\
\text { which indicates that } \\
\text { differences between } \\
\text { male and female } \\
\text { students with respect to } \\
\text { self-esteem and } \\
\text { nomophobia were } \\
\text { significant. The study } \\
\text { demonstrated } \\
\text { differences between } \\
\text { Turkish and Pakistani } \\
\text { students' score on } \\
\text { nomophobia, loneliness } \\
\text { and self-happiness were } \\
\text { significant, while } \\
\text { difference on self- } \\
\text { esteem across countries } \\
\text { was not statistically } \\
\text { significant. }\end{array}$ \\
\hline
\end{tabular}




\begin{tabular}{|c|c|c|c|}
\hline 7 & $\begin{array}{c}\text { Jessica S. Mendoza } \\
\text {,Benjamin C. Pody, } \\
\text { Seungyeon Lee, } \\
\text { Minsung Kim and } \\
\text { IanM.McDonough(2018) }\end{array}$ & $\begin{array}{l}\text { The effect of cell } \\
\text { phones on } \\
\text { attention and } \\
\text { learning: The } \\
\text { influences of } \\
\text { time, distraction, } \\
\text { and nomophobia }\end{array}$ & $\begin{array}{l}\text { Findings indicate that } \\
\text { having cell phones in a } \\
\text { short lecture has its } \\
\text { largest impact on } \\
\text { attention and } \\
\text { learning10E15 min into } \\
\text { the lecture. This study } \\
\text { provides novel insights } \\
\text { into the interactions } \\
\text { between technology and } \\
\text { learning to help } \\
\text { educators and students } \\
\text { optimize learning. }\end{array}$ \\
\hline 8 & $\begin{array}{c}\text { Gabriel Aguilera- } \\
\text { Manrique, VeroAnicaV. } \\
\text { MaArquez-HernaAndez, } \\
\text { Tania Alcaraz- } \\
\text { CoArdoba , Genoveva } \\
\text { Granados-GaAmez1,2³, } \\
\text { Vanesa GutieArrez- } \\
\text { Puertas and } \\
\text { Lorena GutieArrez- } \\
\text { Puertas (2018) }\end{array}$ & $\begin{array}{l}\text { The relationship } \\
\text { between } \\
\text { nomophobia and } \\
\text { the distraction } \\
\text { associated with } \\
\text { smartphone } \\
\text { use among } \\
\text { nursing students } \\
\text { in their clinical } \\
\text { practicum }\end{array}$ & $\begin{array}{l}\text { A positive correlation } \\
\text { between the use of } \\
\text { smartphones and the } \\
\text { total score of } \\
\text { nomophobia } \\
\text { Was found. In the same } \\
\text { way, there was a } \\
\text { positive correlation } \\
\text { between opinion about } \\
\text { smartphone } \\
\text { restriction polices with } \\
\text { each of the dimensions } \\
\text { of nomophobia and the } \\
\text { total score of } \\
\text { the questionnaire }\end{array}$ \\
\hline 9 & $\begin{array}{l}\text { Azra Daei, Hasan } \\
\text { Ashrafi-rizi, and } \\
\text { Mohammad Reza } \\
\text { Soleymani (2019) }\end{array}$ & $\begin{array}{l}\text { Nomophobia and } \\
\text { Health Hazards: } \\
\text { Smartphone Use } \\
\text { and Addiction } \\
\text { Among University } \\
\text { Students }\end{array}$ & $\begin{array}{l}\text { The incidence rate of } \\
\text { nomophobia among the } \\
\text { students was moderate } \\
(3.1) \text {, and } 73 \% \text { of the } \\
\text { students were moderate } \\
\text { smartphone users. } \\
\text { Nomophobia had a } \\
\text { significant relationship } \\
\text { with gender, age group, } \\
\text { and level of education; } \\
\text { and the frequency of } \\
\text { using smartphones had a } \\
\text { significant relationship } \\
\text { with age group and level } \\
\text { of education. There was } \\
\text { a positive correlation } \\
\text { coefficient between } \\
\text { nomophobia and the } \\
\text { frequency of using } \\
\text { smartphones. The } \\
\text { mobile phone use } \\
\text { predicted nomophobia } \\
\text { with a beta coefficient of } \\
0.402 \text { (P < 0.05). }\end{array}$ \\
\hline
\end{tabular}




\begin{tabular}{|c|c|c|c|}
\hline 10 & $\begin{array}{c}\text { G. Jilisha, J. } \\
\text { Venkatachalam, and } \\
\text { Jeby Jose Olickal (2019) }\end{array}$ & $\begin{array}{c}\text { Nomophobia: A } \\
\text { Mixed-Methods } \\
\text { Study on } \\
\text { Prevalence, } \\
\text { Associated } \\
\text { Factors, and } \\
\text { Perception among } \\
\text { College Students } \\
\text { in Puducherry, } \\
\text { India (2019) }\end{array}$ & $\begin{array}{c}\text { Among the } 774 \\
\text { participants, } 23.5 \% \text { had } \\
\text { severe nomophobia } \\
\text { scores. Older age, male } \\
\text { gender, duration and } \\
\text { frequency of } \\
\text { smartphone usage, use } \\
\text { for social networking, } \\
\text { checking without } \\
\text { reason, and checking } \\
\text { Smartphone after } \\
\text { waking up in the } \\
\text { morning were } \\
\text { significantly associated } \\
\text { with nomophobia. The } \\
\text { in-depth interview } \\
\text { showed } \\
\text { attributes of addiction } \\
\text { among the students, like } \\
\text { dependency and } \\
\text { compulsive behaviour. } \\
\text { Students also } \\
\text { experienced anxiety and } \\
\text { frustration when they } \\
\text { had to part with their } \\
\text { smartphones. }\end{array}$ \\
\hline
\end{tabular}

The evaluation of studies published that most of the studies have been conducted amongst college students, clinical students, nursing students, and young adults. When analysing the type of study, it can be seen that majority of the research had been exploratory or qualitative in nature and some used each quantitative and qualitative approach. A very few research had been of experimental type.

Most of the studies had been aimed to learn about the dimensions of nomophobia, incidence of nomophobia, factors affecting nomophobia, grasp of nomophobic sypmtoms and controlling elements for nomophobia .According to the investigator there are four dimensions of nomophobia. These dimensions are: (1) now not being capable to communicate, (2) dropping connectedness, (3) not being capable to get entry to statistics and (4) giving up convenience. Studies on Turkish college students disclosed that the college college students said higher stages of worry for the two dimensions of nomophobia, namely "not being to communicate" and "not being in a position to get entry to information", attesting to the importance of communication and statistics get admission to for young adults. Researchers located that $23.5 \%$ had occurrence nomophobia amongst university students in puducherry India. Alahmari et al. found a occurrence of $22 \%$ for severe nomophobia amongst undergraduate college students in Saudi Arabia. Oksman \& Turtiainen, 2004; Toda et al., 2006: Choliz, 2010; King et al., 2013; Sharma et al., 2015; Tavolacci et al., 2015; Yildirim et al., 2015;
Adnan \& Gezgin, 2016: Gezgin et al., 2017) found that prevalence of nomophobia and its relationship between the other psychological structures

Factors associated with nomophobia are gender and age. G Jilisha et al discovered association between male gender and or work. Azra Daei et al 2019 discovered that statistically large relationship between nomophobia disease and gender, and that its prevalence was once higher in men than in women. The effects of this study are consistent with these of a learn about by means of Majidaei et al., Emelin et al. Yaseminejad et al., and Yildirim et al. Psychological studies exhibit that $70 \%$ of girls and $61 \%$ of guys are afraid of being besides a mobile phone. Study of Arpaci et al. confirmed considerable gender variations in nomophobia, the place female scored extensively greater than men. In contrast, research via Zamani et al., Adawi et al., and Pavithra et al. showed no relationship between nomophobia disease and gender. Azra Daei et al 2019 located that nomophobia and the frequency of over use of mobile cellphone had a statistically enormous relationship with age. Between inconsistent studies, the find out about carried out by means of Yildirim et al. and Argumosa-Villar et al., which showed that age did no longer have any outcomes on individuals' nomophobic behaviors is noteworthy. Study carried out by Emelin et al. discovered a correlation between age and immoderate use of cell phones. Farooqui and Gothankar trust that the age which can be most affected by using nomophobia is between 20 and 24 
years due to the fact young human beings hire new applied sciences and equipment faster than different people.G Jilisha et al determined that (38\%) university college students in puduchery India felt that smartphone use hampered the academic performance. Similar end result used to be recorded through Pavithra and Suwarna Madhukumar where $43 \%$ of medical undergraduate $\mathrm{s}$ expressed worries regarding their lecturers due to uncontrolled smartphone usage. Farooqui et al. Pooja et al. and Chandak et al. also observed a comparable good sized affiliation among undergraduate and postgraduate degree students and amongst clinical undergraduates. Hours of use of cell cellphone predicts nomophobia .Azra Daei et al 2019 determined that frequency of over use of cell cellphone expected nomophobia, Pavithra et al. confirmed that nomophobia ratings were greater in college students who used their smartphones greater than three $\mathrm{h}$ a day. Adawi et al. confirmed that nomophobia was related with the quantity of hours spent on cellular phones. In contrast, the findings of the study via Emelin et al. confirmed that the frequency of UMPs was now not a predictor of mental dependence, and that the frequency of UMPs should no longer have a considerable relationship with mobile smartphone dependence

Hours of smart smartphone use among $35 \%$ of the medical postgraduates who used their smartphones for extra than 3 hours in contrast to these who used much less than 3 hours. A find out about carried out in Saudi Arabia among fitness science beneath graduates also determined an association between nomophobia and make bigger in smartphone usage. Significant danger for nomophobia are also found by many investigators .G Jilisha et al discovered that a massive threat for nomophobia in college students whose cause of maximum use was once social networking and texting. Studies with the aid of Kanmani et al. and Pavithra and Suwarna Madhukumar have additionally found social networking having the best share of customers amongst medical undergraduates, ranging from $56 \%$ to $77 \%$. Studies from Turkey and Spain also had said social networking as the most ordinary undertaking amongst smartphone users. Smartphone is an vital tool which can link extraordinary people, especially household and friends. This turns into greater evident when younger adults have to remain away from home for higher training however would possibly be in need of help to reduce their smartphone usage physical symptoms was seen amongst clinical postgraduates by means of Chandak et al. G Jilisha et al located that fitness effects via the usage of a smartphone additionally (37\%). Khan's study, conducted among undergraduates in Saudi Arabia, also confirmed a extensive relationship between fitness problems and the length of use smartphone. Studies derived the factors of nomophobic behaviour. That are easy to communicate, connectedness, comfort etc. This study is correlated with the issues of a Turkish find out about by means of Caglar Yildirim, such as the incapacity to communicate, inconvenience, and data accessibility. G Jilisha et al also discovered that nomophobic behaviour that are connectedness, get right of entry to information, staying updated, relieving boredom, convenience, etc.

Lidia et al. study located that personality trait self-esteem having a necessary have an effect on nomophobia.

Jilisha et al discovered that smartphone as an imperative technology, a popularity symbol, and a device for social acceptability. This may circuitously suggest a need to have admire among others in the society. Lapointe et al. described attributes of dependancy such as withdrawal, preoccupation, etc., which had been in accordance with the codes dependency and loss of control determined in our study

\section{CONCLUSION}

Reviewing the literature has delivered a deep appreciation on the idea of nomophobia, its dimensions and symptoms. From majority of studies it can be realized that all authors approached the trouble and seen from one-of-a-kind angles. Nomophobia is frequent amongst all the age group, however normally considered in younger adults. It reasons physiological, psychological and social problems. Nomophobia, or no cell smartphone fear, is a truth in today's society where smartphone use has a massive function in people's health/wellbeing and their adjustment to the world they stay in.

Symptoms of nomophobia include stress, anxiety, depression, loss of control, aggression, irritability etc. controlling elements of nomophobia include restrict from family, security concern, destructive fitness effects etc. Prevalence of nomophobia can be viewed in all age companies and gender .There are four dimensions of nomophobia that are not being able to communicate, losing connectedness, no longer being in a position to get admission to records and giving up convenience. Smartphone as a fundamental device which can link special people, especially household and friends. Over use of mobile smartphone will increase the hazard for nomophobia.

\section{IMPLICATION AND SUGGESTIONS}

Increasing use of smartphones and nomophobia is increasing amongst adolescents. To prevent or reduce the terrible impact of nomophobia, it is essential that teachers, families, and society have an recognition of the hassle and be geared up with expertise to help the victims of it. Should provide attention to adolescents that, smartphones are necessary however can't exchange actual 
relationships. Families and teachers ought to apprehend the results of smartphones on adolescents.

It may appear attractive for lonely human beings to establish relationships and socialize via the use of smartphones; however, it ought to be kept in thought that loneliness will hold growing over time. encourage youth to have new hobbies, participate in sports they like or play music, read, and take part in cultural things to do watching a film, going to drama, to musicals and so forth so that humans preserve themselves away from smartphones, it helps them with socializing, overcome the fear of incapability to use a smartphone, and stroll away from the feeling of loneliness

\section{REFERENCES}

1. Daei, A., Ashrafi-Rizi, H., \& Soleymani, M. R. (2019). Nomophobia and health hazards: Smartphone use and addiction among university students. International journal of preventive medicine, 10.

2. Yildirim, C., Sumuer, E., Adnan, M., \& Yildirim, $S$. (2015). A growing fear: Prevalence of nomophobia among Turkish college students. Information Development, 32(5), 13221331.

3. Pavithra, M. B., Madhukumar, S., \& Mahadeva, M. (2015). A study on nomophobia-mobile phone dependence, among students of a medical college in Bangalore. National Journal of community medicine, 6(3), 340-344.

4. Sharma, N., Sharma, P., Sharma, N., \& Wavare, R. R. (2015). Rising concern of nomophobia amongst Indian medical students. International Journal of Research in Medical Sciences, 3(3), 705-707.

5. Ozdemir, B., Cakir, O., \& Hussain, I. (2018). Prevalence of Nomophobia among university students: A comparative study of Pakistani and Turkish undergraduate students. Eurasia Journal of Mathematics, Science and Technology Education, 14(4), 1519-1532.

6. Gezgin, D. M., Hamutoglu, N. B., Sezen-Gultekin, G., \& Ayas, T. (2018). The Relationship between Nomophobia and Loneliness among Turkish Adolescents. International Journal of Research in Education and Science, 4(2), 358-374.

7. Jilisha, G., Venkatachalam, J., Menon, V., \& Olickal, J. J. (2019). Nomophobia: A mixedmethods study on prevalence, associated factors, and perception among college students in Puducherry, India. Indian journal of psychological medicine, 41(6), 541-548.

8. Mendoza, J. S., Pody, B. C., Lee, S., Kim, M., \& McDonough, I. M. (2018). The effect of cellphones on attention and learning: The influences of time, distraction, and nomophobia. Computers in Human Behaviour, 86, 52-60.

9. Aguilera-Manrique, G., Marquez-Hernández, V. V., Alcaraz-Cordoba, T., Granados-Gamez, G., Gutierrez-Puertas, V., \& Gutierrez-Puertas, L. (2018). The relationship between nomophobia and the distraction associated with smartphone use among nursing students in their clinical practicum. PloS one, 13(8), e0202953.

10. Arpaci, I., Baloglu, M., Kozan, H. I. O., \& Kesici, S. (2017). Individual differences in the relationship between attachment and nomophobia among college students: The mediating role of mindfulness. Journal of Medical Internet Research, 19(12), e404. 